\title{
Depths of magma chambers at three volcanic provinces in the Karlova region of Eastern Turkey
}

\section{Özgür Karaoğlu ${ }^{*}$, John Browning, ${ }^{2,3}$, Mohamed K. Salah ${ }^{4}$, Abdelsalam Elshaafi ${ }^{5}$, Agust Gudmundsson 6}

${ }^{1}$ Eskişehir Osmangazi University, Department of Geological Engineering, 26040 Eskişehir, Turkey

${ }^{2}$ Department of Earth Sciences, University College London, Gower Street, London WC1E 6BT

${ }^{3}$ Department of Mining Engineering and Department of Structural and Geotechnical Engineering, Pontificia Universidad Católica de Chile, Santiago, Chile

${ }^{4}$ Department of Geology, American University of Beirut, Riad El Solh 1107 2020, Beirut, Lebanon

${ }^{5}$ Department of Earth Sciences, Faculty of Sciences, Benghazi University, Libya

${ }^{6}$ Department of Earth Sciences, Royal Holloway University of London, Egham, TW20 0EX, UK

* Correspondence to: Ö. Karaoğlu, ozgur.karaoglu@deu.edu.tr; cougarforever@gmail.com

\section{Abstract}

2 The size of a volcanic eruption, and thus the associated potential hazards, depends partly on the 3 depth, geometry, and size of the source magma chamber. To estimate magma chamber depths and 4 sizes, we apply a newly developed analytical method, based on the aspect ratio (length/thickness) 5 of dikes, to three volcanoes in the Karlıova region of Eastern Turkey, namely Turnadağ, Varto, 6 and Özenç. The results indicate that the depths of the source chambers are between 2 and $4 \mathrm{~km}$ at 7 Turnadağ, 2 to $5 \mathrm{~km}$ at Varto, both of which are located in transtensional tectonic regimes, but 8 from 22 to $27 \mathrm{~km}$ at Özenç, which is located in a convergent tectonic regime. A similar reservoir 9 depth at Özenç is indicated by seismic tomography, and this data also suggests that the reservoir 10 is laterally continuous for more than $40 \mathrm{~km}$. The large volume of ignimbrites $\left(>40 \mathrm{~km}^{3}\right)$ associated 11 with Varto, a collapse caldera, indicates that caldera subsidence may have maintained the excess 12 magmatic pressure (through tectonic forcing) in the chamber over a longer time than during normal 
13 pyroclastic eruptions. The dike aspect ratios further indicate magmatic overpressures of 13-21 MPa

14 for Varto, 13-17 MPa for Turnadağ, and 26-31 MPa for Özenç. The combined results from seismic

15 tomography, analytical models and magma compositions indicate that both Turnadağ and Varto

16 volcanoes, which are typical stratovolcanoes composed of mostly intermediate, and more rarely,

17 acidic magmas, were fed by two very shallow and comparatively small magma chambers (2-5 km

18 depth). Whereas less evolved magmas were erupted from Özenç, which hosts predominantly

19 basaltic and intermediate lavas and dikes that were fed by a deep reservoir at 22-27 km depth. Our

20 tomographic models show that none of the volcanoes are located directly over the centre of a deep

21 magma reservoir. Our data also indicates that the magma in the reservoir has migrated between 34

22 and $40 \mathrm{~km}$ in a right lateral motion (to the east) below Varto and Turnadağ, respectively, and 23

$23 \mathrm{~km}$ in a left lateral motion (to the west) at Özenç over the past $3 \mathrm{Ma}$. This lateral propagation of

24 magma can be explained by tectonic escape of the Anatolian block to the west through the Northern

25 Anatolian Fault and the Varto Fault Zone over the last 6 Ma.

27 Key words: Magma, reservoir, dikes, stress fields, magma chamber depth, seismic tomography

\section{Introduction}

Understanding magma storage is of fundamental importance when considering the likely magnitude, timing and location of volcanic eruptions (e.g. Martel et al. 1998; Cayol et al. 2000;

32 Longpré et al. 2008; Ofeigsson et al. 2011; Browning et al. 2015). For example, magmatic

33 propagation paths are partly related to the crustal depth of the magma source (Bower and Woods

34 1997). It is widely recognized that shallow magma chambers influence crustal stresses such that

35 swarms of inclined sheets, and both radial and ring dikes, are produced (Tibaldi and Pasquaré

36 2008; Bistacchi et al. 2012; Browning and Gudmundsson, 2015), whereas deep reservoirs tend to

37 produce vertical dikes of generally mafic composition (Gudmundsson 1983; Ernst et al. 2001).

38 The type of a volcanic eruption is also closely related to the depth of the volcanoes magma chamber

39 (Bonatti and Harrison 1988; Lipman 1997; Scandone et al. 2007). Long-lived (> 1 Ma) composite

40 volcanoes have been shown to be mostly supplied with magma from shallow magma chambers 
which, in turn, receive their magma from deeper reservoirs (Gudmundsson 2006; Browning et al.

42 2015; Gudmundsson 2016; Karaoğlu et al. 2016). These double-magma chamber systems can be 43 compartmentalized both vertically (in terms of depth) and laterally (Gudmundsson 2012; Karaoğlu 44 et al. 2016, 2017a). The deeper parts of such double-chamber systems (the magma reservoirs) are 45 commonly located in the lower crust or at the crust mantle-boundary (Gudmundsson 2000). In all 46 cases, for an eruption to occur, either the shallow magma chamber, or the deep-seated reservoir or 47 (as is more common) both must rupture so as to propagate a dike, or an inclined sheet, to the 48 surface (Gudmundsson 2006, 2012; Chestler and Grosfils 2013; Le Corvec et al. 2013; Caricchi et 49 al. 2014). Magma chambers are also systems that concentrate stresses and interact mechanically 50 (Martel et al. 1998; Gudmundsson and Andrew 2007; Elshaafi and Gudmundsson 2017a, b). In 51 this regard, few places on Earth show such complex volcanotectonic stress relations as the Karlova 52 region of eastern Turkey, where the Karlova Triple Junction (KTJ) has experienced complex 53 orogenesis and hosted voluminous magma discharge (Karaoğlu et al. 2016). The KTJ hosts 54 complex mechanical interactions between the Arabian, Eurasian and Anatolian plates (Şengör and 55 Yilmaz 1981; Barka 1992; Okay and Tüysüz 1999). The relationship between tectonics and 56 magma propagation in such triple-junction tectonic settings remains poorly understood (as 57 discussed by Hubert-Ferrari et al. 2009; Şengör 2014; Karaoğlu et al. 2017b).

Triple-junctions are characterized by high-heat flow, abundant seismicity, and volcanism (e.g. Furlong and Schwartz 2004; Şengör 2014; Karaoğlu et al. 2017b). The KTJ is a continental triple junction (Şengör 2014) consisting of nonsubductable continental crust (Fig. 1). The convergence between Arabia and Eurasia plates has resulted in escape tectonics to the west of the KTJ (Şengör and Yılmaz 1981; Barka 1992; Reilinger et al. 2006). The extruding block is bounded, and structurally controlled, by two conjugate transform fault zones namely the right-lateral North 64 Anatolian Fault Zone (NAFZ) to the north, and the left-lateral East Anatolian Fault Zone (EAFZ) from the southeast (Fig. 1). The westward extrusion of the Anatolian plate has resulted also in intense seismicity (Barka 1992; Okay and Tüysüz 1999; Bozkurt 2001). GPS data indicate that the

67 eastern part of the Anatolian plate moves at a rate of $20 \mathrm{~mm} / \mathrm{yr}$ with respect to the Eurasian plate 68 (Reilinger et al. 2006), where the total displacement is about $85 \mathrm{~km}$ along the NAFZ over the last 696 Ma (Barka 1992; Şengör et al. 2004; Karaoğlu et al. 2017b).

70 The NAFZ commenced activity around $12 \mathrm{Ma}$, whilst the EAFZ developed around $6 \mathrm{Ma}$ 71 (Şengör et al. 2004; Karaoğlu et al. 2017b). Following the development of the EAFZ, westward 
72 extrusion of the Anatolian plate promoted the initiation of a strike-slip tectonic regime around the

73 KTJ. In this area, complex interactions result in complex lithospheric kinematics including tectonic

74 inversions and uplifts, extensive seismicity, larger-than-normal permeability resulting in increased

75 groundwater flow, and frequent episodes of dike emplacement, some of which culminate in

76 volcanic eruptions (Karaoğlu et al. 2016, 2017b). After a dormant period of $2 \mathrm{Ma}$, the first volcanic

77 activity commenced with regional strain induced by the KTJ at around $3 \mathrm{My}$. Dike emplacement

78 in the southern sector indicates a possible E-W dominant direction of dilation since 3 My

79 (Karaoğlu et al. 2017b). Moreover, westward extrusion of the Anatolian plate generated a

$80 \mathrm{NE}-\mathrm{SW}$-trending extensional/transtensional dominant stress field favoring magmatism at the

81 KTJ. This wedge extrusion was accommodated by high strain and encouraged magmatic paths as

82 feeders for the volcanism. This period represented the initiation of minor volcanic activity caused

83 by major extension where volcanism around the KTJ began around $3 \mathrm{Ma}$ (Hubert-Ferrari et al.

84 2009; Karaoğlu et al. 2017b).

85 Many techniques have been used to estimate magma storage depths over the past decades.

86 The most frequently used are geodetic inversion techniques including inversion of the 'Mogi-

87 model' as applied by Mogi (1958). Seismic tomography (Karaoğlu et al. 2017a), and

88 geobarometric studies (Jellinek and DePaolo 2003) have also been used to obtain the geometry of

89 active magma chambers. Gudmundsson (1983, 1995) and Becerril et al. (2013), however, used

90 dikes modelled as fluid-filled cracks and applied fracture mechanics principles to estimate magma

91 chamber depths. More specifically, seismic methods have been used to determine the locations of

92 shallow and active crustal magma chambers at depths of 3 to $6 \mathrm{~km}$ (e.g. Sanford and Einarsson

93 1982; Orcutt et al. 1984; Macdonald 1986), as well as the locations of deep-seated reservoirs in

94 the lower part of crust or at the crust-mantle boundary at depths ranging from 10 to $60 \mathrm{~km}$ (e.g.

95 Gök et al. 2003; Reed et al. 2014; Lemnifi et al. 2017b). However, fossil magma chambers and

96 plutons cannot always be reliably traced using seismic tomography and geodetic methods (e.g.

97 MacLeod and Yaouancq 2000; Bachmann and Bergantz 2008; Gudmundsson 2012). For example,

98 Becerril et al. (2013) calculated the depth of magma reservoirs supplying dikes at El Hierro

99 (Canary Islands) as being approximately $20 \mathrm{~km}$ below sea-level (bsl), an estimate that was

100 supported by the hypocentral locations of seismic swarms (Becerril et al. 2013). Hence, the aspect

101 ratio of feeder dikes is a useful method in providing a rough estimate of the depth to both ancient

102 and active magma chambers (e.g. Cayol et al. 2000; Annen et al. 2008; Becerril et al. 2013). In 
103 this study, we use both seismic and dike-aspect ratio methods to estimate the depths and excess

104 pressures of magma sources in the Karliova region. Using this approach, dike measurements are 105 combined with analytical fracture-mechanic models and seismic tomography to estimate first106 order depths of magma storage regions for three volcanic provinces in Eastern Turkey.

107 Geologic and tectonic setting

Neotectonic activity in the study area commenced with the north-south intracontinental collision between Arabia and Eurasia which began in the middle-late Miocene (Şengör and Y1lmaz 110 1981; Şengör et al. 1985). Extension of the Anatolian plate, over the last $6 \mathrm{Ma}$, generated a stress 111 field suitable for volcanism around Karlıova (Dhont and Chorowicz 2006; Hubert-Ferrari et al. 112 2009; Karaoğlu et al. 2017b). An ongoing N-S directed shortening phase along the boundary of 113 the Arabian and Eurasian plates allowed the westward mass transfer of Anatolia, which has 114 frequently been considered a rigid plate bounded by the NAFZ and EAFZ both of which meet at 115 Karlıova (Fig. 1) (e.g. Dhont and Chorowicz 2006; Sançar et al. 2015; Karaoğlu et al. 2017b).

116 Following continental collision, there was a period of Neogene-Quaternary volcanism 117 expressed by the formation of stratovolcanoes and eruption of predominantly calc-alkaline 118 products (e.g. Pearce et al. 1990; Y1lmaz et al. 1998; Karaoğlu et al. 2005), as well as minor 119 alkaline rocks (e.g. Innocenti et al. 1976; Alici et al. 2001; Özdemir et al. 2006; Lustrino et al. 120 2010). Quaternary volcanism is confined to the Kula area in western Anatolia, whereas Holocene 121 volcanic activity is more abundant in central, and especially, eastern Anatolia where the most 122 recent activity occurred at the Nemrut volcano in 1441 (Karaoğlu et al. 2005; Italiano et al. 2013).

123 The KTJ is a zone of active continental collision that displays complex inversion-type 124 tectonics (Karaoğlu et al. 2017b; Fig. 1a). The location, timing and geochemical characteristics of 125 its volcanism are impacted by complex interactions between the colliding Eurasian and Afro126 Arabian plates. Escape tectonics of the Anatolian plate to the west gave rise to a strike-slip motion 127 along the NAFZ and EAFZ and contributed to the closure of the Neotethyan Ocean as a result of 128 Arabia-Eurasian convergence (Barka 1992; Okay and Tüysüz 1999; Bozkurt 2001; Lemnifi et al. 129 2017a). Structural and stress data indicate a transitional deformation from pure compression 130 (before $12 \mathrm{Ma}$ ) to inversion tectonics induced by compressional-related extensional/transtensional 131 tectonics (after $12 \mathrm{Ma}$ ) for the KTJ (Karaoğlu et al. 2017b). Volcanism that initiated $\sim 6 \mathrm{Ma}$ is 132 directly associated to incremental and complex deformation within the KTJ. Following the 133 formation of the NAFZ and the EAFZ (Fig. 1a), westward extrusion of the Anatolian block and 
134 inversion tectonics on the Eurasian block induced an E-W dominant stress field which favored 135 magma ascent (e.g. Pearce et al. 1990; Karaoğlu et al. 2017b; Lemnifi et al. 2017a).

\section{Initiation of volcanism at the Karlova triple junction}

Volcanic activity related to the extrusion tectonics of the Anatolian plate started with primarily acidic magma generating eruptions dated between 4.4 and $6.06 \mathrm{Ma}$ (Poidevin et al. 1998). The first indication of this extension-related volcanism (Karaoğlu et al. 2017b) is dated around $6 \mathrm{Ma}$ using a fission track technique from rhyolitic obsidians collected approximately 30 km southwestern of the KTJ on the East Anatolian Fault (EAF) (Poidevin et al. 1998). After a dormant period of $2 \mathrm{Ma}$, the volcanic activity commenced with regional wedge-extrusion related strain induced by the KTJ at around $3 \mathrm{Ma}$ (Karaoğlu et al. 2017b). Radiometric age data show that the first eruptions initiated at 3.6 Ma on the southern flank of the Varto caldera located at the easternmost part of the KTJ (Pearce et al. 1990). Hubert-Ferrari et al. (2009) documented a radiometric age of 3.1 Ma recording the earliest activity on the pivot point of the KTJ. Turnadag volcanism is dated at around 2.8 Ma at the westernmost part of the area (Karaoğlu et al. 2017b). Radiometric age data also indicates that magma migrated from east to west, with time, across the Varto Fault Zone (VFZ), which is a direct continuation of the NAFZ (Karaoğlu et al. 2016, 2017; Fig. 1c). The parallel alignment of dikes in the Özenç volcanic area suggests a maximum principal stress $\left(\sigma_{1}\right)$ in the $\mathrm{N}-\mathrm{S}$ direction and a minimum principal stress $\left(\sigma_{3}\right)$ in the $\mathrm{E}-\mathrm{W}$ direction (e.g. Karaoğlu et al. 2017b). The most recent eruption records are dated between 0.46 and $0.73 \mathrm{Ma}$ from two volcanic domes in the southern part of the Varto caldera (Hubert-Ferrari et al. 2009).

Extensive volcanism, mostly high-K calc-alkaline, occurred in Karlova 3 Ma (Pearce et al. 1990; Hubert-Ferrari et al. 2009; Fig. 1). During this time two polygenetic volcanoes in the eastern part of the KTJ erupted and emplaced mostly intermediate-composition lava flows and

157 dikes (Fig. 1c). The VFZ partly controlled the initiation of the Varto volcano and the Özenç 158 volcanic area (Karaoğlu et al. 2017b; Fig. 1a). The most recent stage of the volcanism in this area, 159 since $\sim 1 \mathrm{Ma}$, is characterized by domes and dike injections. Seismic tomography results suggest 160 a $40 \mathrm{~km}$-wide-zone of interconnected magma pockets or individual magma chambers that are fed 161 from deeper levels where magma is generated through partial melting of the lithosphere (Salah et 162 al. 2011). It has been proposed that there are numerous crustal low-velocity zones, predominantly 163 at $25 \mathrm{~km}$ depth, and also a partially molten zone at 20-30 km depth (Zor et al. 2003). 
Volcano-tectonics and geochemical studies in the region show that volcanic eruptions are mainly fed by dikes (i.e. fluid-driven fractures), many of which are cross-cutting (Fig. 1b). The dikes and their eruptions are associated with three central volcanoes, namely Turnadağ, Varto and Özenç (Karaoğlu et al. 2016, 2017a; Fig. 2a).

Both the Varto caldera complex and the Özenç volcanic province formed in the region experiencing inversion tectonics. This region is characterized by right-lateral and thrust faulting between the Arabian and Eurasian plates, which were predominantly driven by ongoing collision tectonics (Karaoğlu et al. 2017b). In contrast, Turnadağ volcano is located on the Anatolian block which has been subjected to westward extrusion tectonics (Fig. 1c). Petrological constraints and field studies indicate that the three volcanic centers exhibit distinct volcanic facies, and geochemical characteristics which indicate that they are fed from different magma chambers/reservoirs (e.g. Buket and Temel 1998; Hubert-Ferrari et al. 2009; Sançar et al. 2015). (Hubert-Ferrari et al. 2009). It is mostly composed of intermediate volcanic rocks which are dacitic to andesitic, but rarely basaltic, in composition (Buket and Temel 1998; Hubert-Ferrari et al. 2009). In the western part of the KTJ, around Turnadağ volcano, there is an evidence of a shallow magma plumbing system (Karaoğlu et al. 2016). While many dike intrusions are observed in the area between the KTJ and the Turnadağ volcano, lava flows are of comparatively little volume (Karaoğlu et al. 2016, 2017b). The western part of the KTJ experienced rifting due to the movement of the Anatolian block to the west (Karaoğlu et al. 2017b), particularly at the junction point where the flame-like apophyses or fingers of injected magma are common (Fig. 2c). (Karaoğlu et al. 2017b; Fig. 3). The caldera's shape, a semi-circle, is partly due to its southern part being cut by faults (Fig. 1c). Tectonic deformation resulted in the dissection of the southern flank of this volcano mostly by NW-SE-striking dextral, normal and reverse faults. An $\mathrm{N} 85^{\circ} \mathrm{W}$-striking, high-angle normal fault which is sub-parallel to the NAFZ (Fig. 1c) is considered to have formed 191 2017b). The fault has been a major control on magma propagation in this region during the last 1

192 My (Karaoğlu et al. 2017b). Synchronous normal faults show that the region has been directly 193 controlled by a NW-trending extension since the initiation of volcanism around 3.6 Ma in the 194 eastern part of the KTJ (Pearce et al. 1990). 
The Özenç region is characterized mostly by effusive volcanism and is located to the south

196 of the Varto caldera (Figs. 1, 2 and 5). Here, most lavas are dated at 1.96 Ma to 2.67 Ma (Hubert-

197 Ferrari et al. 2009). The Özenç volcanic area is dominated by basaltic lava flows and intrusions

198 (Fig 5), which contrasts with the geology of Turnadağ and Varto volcanoes (Pearce et al. 1990;

199 Buket and Temel 1998; Hubert-Ferrari et al. 2009).

\section{Methodology}

\section{Field measurements}

We measured 21 dikes associated with fissure-fed eruptions at three distinct volcanic centers in Eastern Turkey (Fig. 1b). Field measurements and remote sensing analysis, for obtaining their dimensions, were applied to find out the nature, depth and geometry of the magma sources 206 in the Karliova-Varto volcanic province. The thickness and length of each dikes visible on surface 207 was measured using a tape measure, and its strike measurement was recorded. They were cross208 checked and refined using Google Earth satellite imagery (25-50 cm pixel resolution), along with 209 the geological map of Karaoglu et al. (2017b). The thickness measurements were repeated at least 210 five times along the dike, and then the average values were used for the thickness.

\section{Analytical calculations}

213 In the model used here we assume that magma propagates from a magma 214 chamber/reservoir as fluid-driven fractures (hydrofractures; Gudmundsson 2011), that is, as dikes 215 or inclined sheets. Dikes, as magma-driven fractures, are known to be injected magma from a 216 shallow magma chamber. Most eruptions in stratovolcanoes are fed by inclined sheets that cut the 217 volcano at angles considerably less than $90^{\circ}$, whereas those outside the stratovolcanoes are fed by 218 subvertical regional dikes. Here the term "dike" is used as a generic term, for both inclined sheets 219 and vertical dikes (Gudmundsson 1990; Pinel and Jaupart 2004; Bistachi et al. 2012). More 220 specifically, dike propagation is driven by magmatic overpressure $\left(p_{o}\right)$ due partly to internal excess 221 magmatic pressure in the chamber at the time of its rupture $\left(p_{e}\right)$ and dike/sheet injection. In other 222 words, magma-chamber rupture and dike/sheet injection occurs when the excess pressure in the 
223 chamber reaches the in-situ tensile strength $\left(T_{0}\right)$ of the host rock. As a result, when the following 224 condition is satisfied roof/wall rupture, and dike injection, will occur (Gudmundsson 2011):

$225 \quad p_{l}+p_{e}=\sigma_{3}+T_{0}$

226 here $p_{l}$ is the lithostatic stress and $\sigma_{3}$ is the minimum compressive (maximum tensile) principal

227 stress. Extensive field studies involving thousands of cross-cutting relationships, both among the 228 intrusions themselves as well as between the intrusions and other intersected layers, such as lava 229 flows, show that dikes and inclined sheets are, like other hydrofractures, mostly pure extension 230 fractures. Extension fractures are commonly modelled as mode I cracks (e.g. Gudmundsson 1995, 231 2006, 2011; Tibaldi 2015). In such a case, the $\sigma_{1}$ and the intermediate principal $\left(\sigma_{2}\right)$ stresses are 232 in the plane of the dike, whereas the minimum principal compressive stress $\left(\sigma_{3}\right)$ is perpendicular 233 to the dike/sheet plane. This means that dike and intrusions sheet generally, although not 234 exclusively, follow principal stress planes (Gudmundsson 2011, 2018; Browning and 235 Gudmundsson 2015; Tibaldi 2015) thereby minimizing the energy needed to fracture the rock and 236 form flow path (Gudmundsson 2018). When the dike meets a discontinuity between layers it may 237 become arrested if the magmatic overpressure is not sufficient to overcome both the tensile 238 strength and $\sigma_{3}$ (Delaney and Pollard 1981; Martel et al. 1998; Scandone et al. 2007). In the case 239 where dike propagation arrested, the intrusion may propagate laterally to form a sill (e.g. Scandone 240 et al. 2007; Kusumoto et al. 2013; Barnett and Gudmundsson 2014).

241 When dikes or inclined sheets begin to propagate their magmatic overpressure $\left(P_{0}\right)$ at any 242 vertical distance $h$ above the point of initiation at the boundary of the chamber is given by 243 Gudmundsson (2011) and Kusumoto et al. (2013):

$244 p_{o}=p_{e}+\left(\rho_{r}-\rho_{m}\right) g h+\sigma_{d}$

245 where $\rho_{r}$ is the average density of the host rock, $\rho_{m}$ is the average density of the magma in the 246 dike, $g$ is acceleration due to gravity, $h$ is the depth or dip dimension of the dike and $\sigma_{d}$ is the 247 differential stress (i.e. the difference between the vertical stress and minimum principal horizontal 248 stress in the area where the dike is observed). 
Most of the dikes observed in the field were vertical to sub-vertical and so we concentrate 250 our analytical method on dikes rather than inclined sheets. At the point of initiation, the buoyancy 251 term $\left(\rho_{r}-\rho_{m}\right)$ in Eq. (2) is zero, but as the dike propagates its height above point of initiation 252 increases, and thus buoyancy affects the overpressure (Murase and McBirney 1973; Tibaldi and 253 Pasquarè 2008). For basaltic dikes injected from a shallow chamber (1-3 km depth), the buoyancy 254 can be negative (magma density greater than the average density of the host rock), positive (i.e. magma density is less than that of the host rock), or zero (i.e. magma density is equal to that of the 256 host rock) - the latter case is also referred to as neutral buoyancy (Murase and McBirney 1973; 257 Tibaldi and Pasquarè 2008; Gudmundsson 2011). For intermediate and acid magmas the buoyancy 258 term is generally positive (Murase and McBirney 1973; Gudmundsson 2011). As the average 259 density of andesitic magmas $\left(2475 \mathrm{~kg} \mathrm{~m}^{-3}\right)$ is generally less than the average density of the upper crust in eastern Turkey $\left(2800 \mathrm{~kg} \mathrm{~m}^{-3}\right)$, the magma will likely generate an overpressure as it travels upwards through the crust (Eq. 2) (e.g. Murase and McBirney 1973; Kushiro 1980; Gudmundsson 2011). Overpressure $\left(p_{0}\right)$ in a feeder dike is thus of great importance for the eruption mechanism because overpressure controls partly the volumetric or effusion flow rate through the associated volcanic fissure (Parsons and Thompson 1991; Gudmundsson 2011; Kavanagh et al. 2015).

The volumetric flow rate of magma through a dike is a function of viscosity (assumed constant in this model) and overpressure, and the opening or aperture of the dike (e.g. Sanford and 267 Einarsson 1982). The paleo-aperture of a dike is (to a first approximation) equal to its thickness, this being the difference between opening and thickness (reduction in opening as the magma solidifies) which is often around 10\% (Gudmundsson 2011). The thickness (or opening) ratio of a dike and overpressure are normally smaller near the magma source than in the upper part of the crust (Delaney and Pollard 1981; Chaussard and Amelung 2014). This follows because (1) the

272 Young's modulus for stiffness gradually, albeit irregularly, increases with depth, and (2) buoyancy 273 contributes positively to magmatic overpressure with increasing height $h$ above the source (Eq. 2), 274 as long as the average density of the layers that the dike propagates through is higher than the 275 density of the dike magma (Parsons and Thompson 1991; Matel 1998; Pinel and Jaupart 2004; 276 Tibaldi and Pasquarè 2008; Gudmundsson 2011). Buoyancy is generally positive for all acid and 277 intermediate magmas, as well as for the most common basaltic magmas except in the near-surface 278 parts of the crust, as such when individual dikes are traced along dip with depth, they commonly 279 become thinner (Pinel and Jaupart 2004; Tibaldi and Pasquarè 2008; Geshi et al. 2010). 
Dike length should increase with depth in order to keep the volume rate of magma flow in the lower part of the dike equal to that in the upper part (Gudmundsson 1990). Many field measurements of the variation in dike thickness along strike show that the dike geometry in plan view is, to a first approximation, commonly that of a flat ellipse (Delaney and Pollard 1981;

284 Gudmundsson 1983; Pollard and Segall 1987). The same geometry is observed for many other fluid-driven fractures, that is, hydrofractures (Valko and Economides 1995; Yew 1997; Kusumoto et al. 2013; Kusumoto and Gudmundsson 2014). This geometry suggests that the overpressure when the fracture propagation comes to an end is roughly uniform because for uniform pressure a crack should open up into a flat ellipse (Sneddon and Lowengrup 1969; Valko and Economides 1995; Gudmundsson 2011). Therefore, for dikes, the magmatic overpressures can be estimated as a first-order approximation from the aspect (length/thickness) ratio of the dike, including feederdikes/volcanic fissures, volcanic fissures according to Sneddon and Lowengrub (1969), Pollard and Segall (1987) and Gudmundsson (2011)

$293 \quad p_{0}=\frac{\Delta u E}{2 L\left(1-v^{2}\right)}$

294 here $v$ is the Poisson ratio, and $E$ is the Young's modulus of the host rock, $\Delta u$ is the maximum 295 thickness (or opening) of the dike, and $L$ is the horizontal length of the dike (Fig 1b). Because of 296 the flat ellipse geometry discussed above, the maximum thickness can be taken as the measured 297 average thickness of the dike in any section, so long as the sections are far from the lateral ends/tips 298 of the dike (Gudmundsson 2011; Becerril et al. 2013). In the present study, the length and thickness of 21 dikes have been measured (Table 1). In order to minimize measurement uncertainty, multiple measurements of the same dike were made and the repeated measurements were then averaged. Measurements commonly possess an uncertainty of $\pm 5 \%$.

The crustal segment of the Karlıova region consists of a pile of thick lava flows, layers and units of pyroclastic rocks, intrusive gabbro and granites, metamorphic rocks, as well as highly damaged fault rocks overlain by about $2 \mathrm{~km}$ of various types of sedimentary rocks and unconsolidated sediments (Türkünal 1980; Karaoğlu et al. 2017b). The density of such materials can normally range between 2000 and $3100 \mathrm{~kg} \mathrm{~m}^{-3}$ (Gudmundsson 2011). Here we use an average crustal density of $2800 \mathrm{~kg} \mathrm{~m}^{-3}$ which is similar to the average density of the upper crust in many places around the world such as the rift zones in Iceland and central Libya (e.g. Sanford and 
Einarsson 1982; Gudmundsson 1990; Reed et al. 2014; Elshaafi and Gudmundsson 2017a). The

310 static Young's modulus for the uppermost crust in this part of Turkey, based on laboratory tests 311 on core samples, has been estimated to be the range 5-40 GPa (Gurocak et al. 2012; Karaoğlu et 312 al. 2016). However, the in-situ Young's modulus is likely to be lower (by 1.5 to five times) than 313 laboratory measurements due to the existence of fractures, cavities and planes of weakness that are 314 not well-represented in the core samples measured in the laboratory (Gudmundsson 2011). In this 315 study, we thus use an average crustal static Young's modulus of $5 \mathrm{GPa}$, and a typical Poisson's 316 ratio of 0.25 . While this Young's modulus is low, it is similar to the estimated static modulus for 317 the thick Holocene pahoehoe lava flows, and the Pleistocene surface pyroclastic rocks and units, 318 including hyaloclastites, in the rift zone of Iceland (Gudmundsson 2006).

\section{Tomographic methods}

Seismic-tomography methods have been previously applied to detect active magma chambers and reservoirs (e.g. West et al. 2001; Singh et al. 2006; Lees 2007). In addition, the technique is also used to ascertain the location of partially solidified magmatic bodies in long-lived volcanic areas particularly at Quaternary volcanoes (Konstantinou et al. 2007; Annen et al. 2008). The last volcanic activity in the Karlıova-Varto region is known to have occurred 0.46 Ma, although the region has been active since $2.8 \mathrm{Ma}$ (Hubert-Ferrari et al. 2009). In addition, the presence of active volcanism is known in this region and its immediate vicinity. The Nemrut Caldera volcano is located $85 \mathrm{~km}$ southeast of the Karlova-Varto region, and is known as one of Turkey's most active volcanic areas (Karaoğlu et al. 2005). The last volcanic activity documented for the Quaternary Nemrut volcano was in 1441 AD (Karaoğlu et al. 2005). Thus, it is thought that the magma reservoir detected in the Karlıova-Varto region is strongly associated with long-lived ( $<3 \mathrm{Ma}$ ) volcanic activity. In this study, we used the seismic velocity model derived by Salah et al. (2011)

332 for the eastern Anatolia to construct three new vertical cross-sections of P- and S-wave velocities, as well as the variation in the Poisson's ratio (v) across the Varto-Karlova volcanic region (Fig.

334 6). This model was obtained by applying the tomography method of Zhao et al. $(1992,1994)$ on 335 the arrival times of body waves generated by local shallow earthquakes in eastern Anatolia based on seismic data set of GEOFON and the Turknet (Turkish National Telemetric Earthquake 337 Network). The method of Zhao et al. (1992, 1994, 2012) has been applied successfully to arrival 338 times for seismic events occurring in a wide range of tectonic environments (Salah et al. 2011; 339 Şengör and Yılmaz 1981; Barka 1992; Okay and Tüysüz 1999). It is adaptable to a general velocity 
structure which includes several seismic velocity discontinuities, resulting in a complex topography (Zor et al. 2003; Gök et al. 2011; Lemnifi et al. 2017a). Initially, a 3-D grid is set for

342 the model space so as to express the 3-D velocity variations. The seismic velocities are then taken 343 as unknown parameters. Velocity at any point in the model is calculated by linear interpolation of 344 the velocity values at the eight grid nodes surrounding that point. The method uses an efficient 3345 D ray-tracing scheme which accurately calculates travel times and ray-paths. More details about 346 the method can be found in Zhao et al. $(1992,1994,2012)$.

The eastern Turkey data set comprises $31730 \mathrm{P}$-wave and $29320 \mathrm{~S}$-wave arrival times generated by 7380 seismic events recorded at 39 seismic stations distributed relatively uniformly in the study area (Salah et al. 2011). Analysis of the ray-path coverage (both in plan and vertical views) with results of the checkerboard resolution tests and hit count rates all imply that the obtained velocity anomalies are reliable to a depth of $45 \mathrm{~km}$ (Salah et al. 2011). Seismic wave velocities and Poisson's ratio (v) along the selected three cross-sections are shown in Figure 6.

\section{Results}

All of the measured dikes are essentially planar with no significant elliptical geometry, particularly in terms of variations in thickness along the length. Therefore, thickness and length measurements were performed together. We here follow the chemical analysis of Buket and Temel (1998); Hubert-Ferrari et al. (2009) and Pearce et al. (1990) for definition of dikes at Turnadağ, Varto and Özenç volcanoes, respectively.

\section{Turnadağ volcano}

Of the 21 dikes measured at the three volcanoes, seven dikes were observed and measured at the Turnadağ volcano. These dikes display NE-SW-orientation, with azimuths ranging from $36265^{\circ}$ to $81^{\circ}$ and a mean of $70^{\circ}$ (Fig. 2b). The general strike of the dikes indicates a stress field with $363 \sigma_{3}$ in the NW-SE direction which is subparallel with the recent direction of movement of the 364 Anatolian block.

\section{Varto volcano}

Dikes at Varto are primarily trachy-basaltic and, more rarely, dacitic (Fig. 2d). The six 367 dikes measured at Varto display WNW-ESE orientations with only one dike striking NE-SW 368 (Figs. 3a, b). The dikes have a mean strike of $282^{\circ}$ but vary between $300^{\circ}$ and $205^{\circ}$ (Fig. 1b). 
Based on Ar-Ar dating, the dikes have ages ranging from $\sim 0.4$ to $0.7 \mathrm{Ma}$ (Hubert-Ferrari et al. 2009). In the Varto caldera, however, the range is much greater between 3.6 and $0.46 \mathrm{Ma}$ (Pearce et al. 1990; Hubert-Ferrari et al. 2009). Bimodal or polymodal distribution patterns within the

372 caldera indicate the existence of different local stress fields and resulting dike/sheet swarms (Fig. 373 2e). We recorded (unpublished data) four distinct ignimbrite deposits that reveal the sustained eruption history of the caldera onset event. On the northeastern slopes of the volcano the ignimbrite thickens progressively westwards. Varto's explosive products include widespread, intenselywelded, ignimbrites and lithic breccias (Figs. 2a and 4). The welded ignimbrites include two that are rheomorphic and are concentrated around the western part of the Varto caldera (Fig. 2a). Extensive welded and non-welded ignimbrites outcrop in the northeastern part of this region (in the Hinis region, Fig. 1c). We find three concentric ring faults related to the Varto caldera, cutting the outermost caldera rim, the mega-breccias which are likely associated to roof collapse and postcaldera lava flows inside the caldera (Fig. 4). Varto has, therefore, a nested caldera.

The dikes in the Özenç volcanic region fed effusive-type eruptions mostly of the alkaline and, rarely, sub-alkaline magmas, including basaltic trachy-andesite and basaltic andesite (Buket and Temel 1998; Hubert-Ferrari et al. 2009). We measured seven dikes in the Özenç volcanic region (Fig. 5). Mostly striking in an E-W direction (with a mean of about $88^{\circ}$; Fig. 1b), suggesting a controlling stress field with a $\sigma_{3}$ in the $\mathrm{N}-\mathrm{S}$ direction.

\section{Magmatic overpressure and depth of magma source}

Using the assumed values for the crust as given in Table 1 and the measured field aspect ratios (length/thickness or opening) of the dikes (Table 1), Eq. (3) gives magmatic overpressures ranging from $13 \mathrm{MPa}$ to $31 \mathrm{MPa}$. Breaking this down by volcano, dike overpressures range between $13 \mathrm{MPa}$ and $21 \mathrm{MPa}$ at Varto, between $13 \mathrm{MPa}$ and $17 \mathrm{MPa}$ at Turnadağ, and between $26 \mathrm{MPa}$ and $31 \mathrm{MPa}$ at Özenç. The lower (13-21 MPa) values observed at Varto and Turnadağ are similar to those obtained at many other volcanic provinces that have shallow crustal magma chambers (e.g. Bower and Woods 1997; Dvorak and Dzurisin 1997; Lipman 1997; Troll et al. 2002; Jellinek and DePaolo 2003; Annen et al. 2008; Acocella 2007; Bistacchi et al. 2012). The highest values (26-31 MPa) observed in the Özenç volcanic area are similar to those obtained in deep-seated magma reservoirs in Iceland (Gudmundsson 2000). Generally, the overpressures 
obtained here are similar to those obtained from dike aspect ratios in other regions (e.g. Geshi et al. 2010; Gudmundsson 2011; Becerril et al. 2013).

The inferred overpressures may be used to estimate the depths of magma source by 402 combining Eqs. (2) and (3) (after Becerril et al. 2013) to obtain:

403

$$
h=\frac{\Delta u E}{2 L\left(1-v^{2}\right)\left(\rho_{r}-\rho_{m}\right) g}-\frac{p_{e}+\sigma_{d}}{\left(\rho_{r}-\rho_{m}\right) g}
$$

$405 \quad h=\frac{p_{o}-p_{e}-\sigma_{d}}{\left(\rho_{r}-\rho_{m}\right) g}$

406 the magma chamber/reservoir can be assumed as being essentially equal to the in situ tensile 407 strength of the host rock at the time of rupture and dike injection (Elshaafi and Gudmundsson 408 2016). The estimated average $T_{o}$ of the upper crust in the Varto-Karlova region is around 3.5 $409 \mathrm{MPa}$ (Gurocak et al. 2012; Karaoğlu et al. 2016). This value is consistent with the general range 410 of the in situ tensile strengths measured (mostly through hydraulic fracturing testing) as being 411 between 0.5 and $9 \mathrm{MPa}$ with the most common values being 2-4 MPa (Gudmundsson 2011; 412 Browning et al. 2015; Elshaafi and Gudmundsson 2017). At the Earth's surface, where the dike is 413 exposed, $\sigma_{1}$ is $0.1 \mathrm{MPa}$ (atmospheric) and $\sigma_{3}$ may be in the range $0-2 \mathrm{MPa}$, so that $\sigma_{d}$ is 414 effectively the in-situ tensile stress at failure in the fractured surface layer (Gudmundsson 2011; 415 Becerril et al. 2013). During rifting episodes the main tensile stress concentration occurs around 416 the source of the injected dike, where $\sigma_{d}$ is limited to the tensile strength of the rock (assuming 417 that the magma chamber or reservoir is in mechanical equilibrium before the unrest or rifting 418 episode, as is a reasonable starting assumption (Gudmundsson, 2011). It follows that at shallower 419 levels $(1-3 \mathrm{~km})$, where the dike is exposed today, $\sigma_{d}$ may have been very small. Here, we use the 420 general value of $\sigma_{d}$ as $1 \mathrm{MPa}$. The dikes at Varto and Turnadağ are intermediate in composition 421 so we use a relatively low average magma density of $2475 \mathrm{~kg} \mathrm{~m}^{-3}$ in our models (Murase and 422 McBirney 1973; Kushiro 1980; Gudmundsson 2011). In contrast, the dikes at Özenç are mostly 423 basaltic to basaltic-andesite in composition, and so we use a higher estimated average density of $4242700 \mathrm{~kg} \mathrm{~m}^{-3}$ in our model (Murase and McBirney 1973; Kushiro 1980). These models do not 
425 consider the effect of dynamic gas expansion and vesiculation. In fact, field observations of the 426 dikes suggest that they do not contain many vesicles, and those seen are mostly very small. We 427 therefore expect the effect of vesiculation on magma density to have been small for these dikes. 428 This is in agreement with observations of dikes made elsewhere (Walker 1986; Taisne and Jaupart 429 2011; Pistone et al. 2017). Vesicles in magma (particularly basaltic) are generally small and rare 430 at depths greater than several hundred metres below the surface at the time of dike emplacement 431 (Galindo and Gudmundsson 2012; Gudmundsson 2016). Also, measurements in Hawaii suggest 432 that most of the exsolution of gas in basaltic magmas occurs in the uppermost few hundred metres 433 of the feeder/conduit (Greenland et al. 1988; Eychenne et al. 2015; Ferguson et al. 2016; 434 Moussallam et al. 2016). Thus, the expected reduction in magma density due to gas expansion is 435 unlikely to be of great significance, if at all, except very close to the surface. In addition, the effect 436 of vesiculation on magma density in terms of driving dike propagation is still not well-constrained 437 and requires further investigation.

438 The results in Table 1 show the estimated depths to the source chambers/reservoirs of the 439 dikes in these volcanoes. The depths to the source chambers/reservoirs of the dikes are $2-5 \mathrm{~km}$ at 440 Varto, 2-4 km at Turnadağ, and 26-31 km at Özenç.

\section{Seismic tomography}

442 We use the seismic data to aid the location of magma chambers and determine the geometry 443 of the plumbing systems feeding the volcanoes in this region. The most prominent feature in the 444 velocity models (Fig. 6) are the low-velocity zones or regions coinciding with the locations of the 445 three volcanoes discussed here. Low to moderate seismic velocities and high Poisson's ratios are 446 found in the crust beneath all of the volcanoes (Fig. 6). Prominent low P-wave and S-wave 447 velocities are clearly seen at depths of $25 \mathrm{~km}$ along the three cross sections (two E-W, and one N-

448 S, Fig. 6). Some of these low-velocity zones, originating in the lower crust, extend upwards to 449 shallower crustal depths (Fig. 6). High Poisson's ratio anomalies are also visible at shallow depths. 450 However, the lower-middle crustal depths are characterized by low or average values of Poisson's 451 ratio. The high Poisson's ratios throughout the imaged zones suggest the existence of both 452 comparatively shallow magma chambers (<10 km depth) and also deeper magma reservoirs (10$45340 \mathrm{~km}$ depth) in the southern part of the KTJ. The tomographic images also suggest the existence 454 of magma reservoirs at depths below $10 \mathrm{~km}$ in the Turnadağ and magma reservoirs between 15 455 and $40 \mathrm{~km}$ in the Özenç region. The tomography results are broadly consistent with the analytical 
results obtained from field measurements of dikes erupted 0.5-3 Ma ago, and support the existence 457 of a deep and long-lived magma reservoir.

458 The seismic velocity models show that while the three volcanic centers share a similar 459 active deep magma reservoir, characterized by a prominent low seismic velocity, there are also 460 some small-scale bodies likely comprising lava domes, intrusions, and diapiric injections through 461 the upper crust, surrounded by higher-seismic-velocity zones (Fig. 6). The magma reservoirs 462 extend between 10 and $30 \mathrm{~km}$ in depth and 80-85 km in width, and are oriented in a NNW-SSE463 elongated tabular form (sill-like shape) (Fig. 6). A very prominent dome-shaped injection extends 464 upward from the lower level of the crust in an E-W oriented profile (Fig. 6a). Below Özenç, a less 465 distinctive low velocity zone is observed trending in an E-W direction as shown in the B-B' profile 466 of Figure 6b. In the E-W trending A-A' profile (Fig. 6a), we note that the diapiric-shaped dike 467 injection which appears to feed the main vent of Varto is not aligned below the main volcanic 468 center but instead displaced by $34 \mathrm{~km}$ to the east. It seems that there is no shallow or diapiric469 shaped magma source below Turnadağ according to the Vp model. However, the Vs model 470 indicates a $40 \mathrm{~km}$ displacement of magma chamber to the east in accordance with the migration 471 direction of Varto (Fig. 6b).

\section{Discussion}

473 Using well-established analytical results from fracture mechanics (Sneddon and 474 Lowengrub 1969) which have been widely applied to human-made hydraulic fractures (Valko and 475 Economides 1995; Yew 1997) as well as to natural hydrofractures such as mineral veins 476 (Gudmundsson 1999; Philipp 2012; Kusumoto et al. 2013) and dikes (Gudmundsson 1983; Geshi 477 et al. 2010; Becerril et al. 2013), we use aspect ratios of dikes in the Karliova region of eastern 478 Turkey to interpret the depth to their magma sources. We compare the depth estimates from the 479 dike aspect ratios to those obtained from seismic tomography imaging. The results are in general 480 harmony and indicate that the Karlıova region hosts three distinct magma source regions (Figs. 6 481 and 7). Our results indicate also that the spatial relationship of dikes have not changed substantially 482 over the lifetime of the volcanoes, suggesting that the magma chambers have remained with similar 483 geometries during this time, which is in agreement with magma-chamber studies elsewhere (e.g. 484 Pinel and Jaupart 2004; Annen et al. 2008; Becerril et al. 2013). 
Two factors, the dike opening (thickness) and length of the dikes, are very important to estimate the overpressure and depth to the source chamber. There are a few studies which attempt

487 to estimate the depths of magma by using dike thickness and length measurements (e.g. 488 Gudmundsson, 1983; Becerril et al. 2013; Elshaafi and Gudmundsson 2016). In this study, the 489 results are compared with estimated overpressures, obtained from the aspect ratio of dikes exposed 490 at the surface across two volcanic regions which have quite different tectonic settings. The first 491 setting is characterized by Quaternary volcanic activity which is likely related to hotspot volcanism 492 close to the passive continental margin of El Hierro-Canaria Islands studied by Carracedo et al. 493 (1998). The second setting is the Pliocene-Pleistocene Al Haruj, Libya, volcanic province 494 (AHVP), which is considered to be a typical intra-plate volcanic setting and has been linked to the 495 tectonic evolution of the rifting of the Sirt Basin as described by Elshaafi and Gudmundsson 496 (2016). In Figure 8 we plot the aspect of thickness ( $\Delta u 1)$ to length $(L)$ ratio of the measured dikes 497 against the calculated magma overpressures, measured at El Hierro (as described by Becerril et al, 498 2013), Varto-Karlıova (this study) and Al Haruj (as described by Elshaafi and Gudmundsson, 499 2016). In total, the six dike measurements from El Hierro gave a range of overpressures between 500 11-18 MPa, and it was estimated that these dikes were sourced from at a depth of 8-15 km (Becerril 501 et al. 2013). A total of 47 dike measurements were made at Al Haruj which showed a similar quasi502 exponential trend to the volcanic regions of both El Hierro and Karlova, but it is notable that the 503 magmatic overpressure values are substantially larger (Fig. 8). The $\Delta \mathrm{u} 1 / \mathrm{L}$ ratio values in the $\mathrm{Al}$ 504 Haruj volcanic area (10-37 MPa) are also larger compared to the other volcanic areas. The dike 505 measurements from the three volcanic provinces with different tectonic settings show that the resulting analytical data do not vary significantly between the depths of the magma chambers and 507 the calculated magma overpressures (Fig. 8). The magma overpressure and depth values obtained 508 from the volcanic region of Varto-Karlova which has been controlled in an inversion tectonic 509 setting from transtensional to compressional during the Quaternary (Karaoğlu et al. 2017b) show 510 some similarities, particularly with the El Hierro-Canaria Island volcano. Deeper magma 511 reservoirs with higher magma overpressures in the Karliova-Varto region (12-31 MPa magma 512 overpressure in the Özenç area) exhibit similar trends with the AHVP (10-37 MPa magma 513 overpressure). These results show the reliability of these analytical calculations and their self514 consistency, and help confirm that magmatic zones have similar dynamic properties throughout 515 the lithosphere. 
Varto is the only volcano in the study area which hosts a caldera (Fig. 4). Our results also indicate that the volcano hosts a shallow magma source at a depth of around 2-5 km below the surface (Table 1). For the Turnadağ volcano, located on the Anatolian microplate, our results suggest a shallow magma chamber at 2-4 km depth, that is, of a depth similar to that of the chamber of the Varto volcano. The magma-chamber-depth results for Turnadağ are supported by high Poisson's ratio anomalies at similar depths. These shallow chambers, in turn, are presumably fed with primitive magma from deep reservoirs.

Numerical, analog, and field studies indicate that the cross-sectional shape of an underlying shallow magma chamber in plan view closely resembles that of the associated collapse caldera, whilst the deeper reservoir may be larger than the volcanic edifices they feed and have no geometric correlation with the caldera shape (Gudmundsson 2012, 2015; Gerbault 2012; Gregg et al. 2013; Grosfils 2007; Grosfils et al. 2015; Browning and Gudmundsson 2015). Large volume intermediate and acidic lavas and pyroclastics erupted from stratovolcanoes, particularly calderaforming volcanoes, most likely require a shallow magma chamber fed by a deeper reservoir (e.g. Ofeigsson et al. 2011; Gudmundsson 2012, 2015; Karaoğlu et al. 2017a). For the Varto volcano, caldera diameter and depth are almost identical to that of the Nemrut caldera (Karaoğlu et al. 2005), which has produced up to $64 \mathrm{~km}^{3}$ of ignimbrite from the successive eruptions (Karaoğlu et al. 2005). When taken together, the felsic rock composition large volume ignimbrites and caldera formation indicate that Varto was likely fed from a shallow chamber. The subsidence of some caldera floors exceeds $2 \mathrm{~km}$ (Gudmundsson 2015, 2016). Subsidence of a caldera block along ring faults and gas-rich magma played an important role in keeping excess magmatic pressure sufficiently high for a much longer period of time in order to squeeze a higher volume of magma than 'normal' eruptions of the Turnadağ and Özenç volcanoes (cf. Gudmundsson 2015, 2016). The eruptive volume of 'normal' eruptions can commonly be considered of the order of $0.1 \%$ of the bulk volume of a chamber/reservoir (Browning et al. 2015; Gudmundsson 2016). We thus assume that the eruptive material associated with a collapse caldera is likely many orders of magnitude greater than generated in 'normal' eruptions.

Özenç has erupted primarily mafic lavas, mostly of the alkaline and, rarely, sub-alkaline

545 Temel 1998; Hubert-Ferrari et al. 2009). The dike segments and volcanic fissures have on average higher ratio of length $(270 \mathrm{~m})$ to thickness $(3 \mathrm{~m})$ than in the other two volcanoes (Figs 3, 4, Table 
547 1). The thickness/length ratios of dikes in the study area and in the AHVP, for comparison, is 548 inversely proportional to magmatic overpressure. It is important to note that both volcanic 549 provinces have similar statistical relationships although there is a variation in the ratio values (Fig. 550 3). Our calculations indicate that the dikes were generated by a higher magma overpressure and 551 therefore formed from a deeper magma storage system at around 26-31 km depth. We assume that these dikes were fed directly from this deep source rather than through a shallow magma system. The seismic tomography data coupled with our field measurements suggest that the deep reservoir may have migrated laterally over $23-40 \mathrm{~km}$ following the formation of the volcano over the past $3 \mathrm{Ma}$. The movement vector of the Anatolian plate based on GPS data of Reilinger et al. (2006) corresponds to an axis of principal stress between $23 \mathrm{~km}$ and $40 \mathrm{~km}$ (Fig. 6). However, the lack of data concerning the petrology, specifically pressure-temperature (PT) calculations for the volcanic products in the Karlıva-Varto volcanic province, makes further analysis challenging. We therefore encourage a systematic field survey which would greatly improve the understanding of this volcanism. We recommend further research into this volcanic province in order to better understand the particularly deep-source-fed magma plumbing mechanism.

We regard the first two depth values of Varto and Turnadağ as very robust, while the depth to the source for the Özenç dikes is less certain. The depths to the chambers of Varto and Turnadağ are very similar to those obtained by various methods for shallow chambers in other volcanotectonic areas worldwide (Gudmundsson 2006; Chaussard and Amelung 2014), whereas the source at Özenç would be regarded as a deep-seated reservoir by Gudmundsson (2006) and similar in depth to the basaltic volcanic field of AHVP in central Libya as studied by Elshaafi and Gudmundsson (2016, 2017b).

These volcanoes formed through an intensely deformed lithosphere and mainly erupted calc-alkalic andesite and basalt products (Karaoğlu et al. 2017b) indicating that the crust has been

572 the study of Italiano et al. (2013).

In none of the tomographic profiles is the volcano located directly over the centre of the

574 large deeper reservoir (Fig. 6). This suggests that either (1) the reservoir has migrated laterally 575 since the initiation of these volcanoes during the past $3 \mathrm{Ma}$, or (2) tilting of the pile of lavas and 576 pyroclastics that constitute the crust results in dike paths being somewhat inclined, resulting in the 577 source being to one side of the volcano. The profiles show $\sim 34$ and $40 \mathrm{~km}$ in right lateral 
578 displacement (to the east) below Varto and Turnadağ, respectively, and a $23 \mathrm{~km}$ left lateral 579 migration (to the west) for Özenç (Fig. 6a-b). This migration can be explained by wedge extrusion tectonics of the Anatolian block to the west through the NAFZ and VFZ since 6 Ma (Fig. 1c). It seems that the Turnadağ and Varto volcanic edifices might be displaced to the west (Karaoğlu et al. 2017b), whereas the magma chambers may have reacted in a completely opposite direction to this movement of the crust showing plastic deformation. The Özenç volcanic region does not exhibit the same mechanism of movement as Varto and Turnadağ due to its position outside this laterally moving crust (Figs. 1c and 7).

Our results are consistent with a region of high temperatures and partial melt in the crust underneath Varto caldera. A significant amount of melt must be generated below Varto caldera during times of caldera-related and voluminous ignimbrite and tuff deposition (e.g. Aldiss and Ghazali 1984; Stankiewicz et al. 2010; Karaoğlu et al. 2016). Similarly low P-wave velocity anomalies, to those observed in this study, have also been recorded beneath Toba caldera in Indonesia (Stankiewicz et al. 2010); Yellowstone caldera in North America (Stachnik et al. 2008)

592 and the Altiplano-Puna volcanic zone in the Chilean magmatic arc (Graeber and Asch 593 1999; Haberland and Rietbrock 2001), and also likely indicate regions of high temperature and 594 partial melt.

\section{Conclusions}

Our field observations and analytical results indicate the presence of shallow magma chambers beneath the volcanoes of Varto and Turnadağ at depths of 2-5 km. In contrast, we obtain 598 a deeper magma system located between 22 to $27 \mathrm{~km}$ below the Özenç volcanic province (Fig. 5). 599 Seismic tomography images support the existence of magma chambers at depths between 3-10 km 600 below the areas hosting Turnadağ and Varto. The tomographic imaging technique also points to a 601 deep magma reservoir residing between $15 \mathrm{~km}$ and $30 \mathrm{~km}$ in the Özenç region. The images indicate 602 that the magma reservoir is laterally continuous for more than $40 \mathrm{~km}$. These new estimates of 603 magma-chamber/reservoir depths are in close agreement with previous findings from finite 604 element modelling numerical analysis (Karaoğlu et al. 2016).

We also use feeder-dike aspect ratios to calculate magmatic overpressures during dike 
607 Varto, from 13 to $17 \mathrm{MPa}$ in Turnadağ, and from 26 to $31 \mathrm{MPa}$ in Özenç. These results seem 608 reasonable as the lower (13-21 MPa) overpressure values observed in Varto and Turnadağ are 609 similar to those obtained in many other volcanic provinces that have shallow crustal magma 610 chambers (Gudmundsson 1983; Becerril et al. 2013; Browning et al. 2015). The highest values 611 (26-30 MPa) are similar to those obtained for dikes injected from deep-seated magma reservoirs 612 in Iceland and Libya (Gudmundsson 2000; Elshaafi and Gudmundsson 2016).

613 The results of seismic tomography broadly support the analytical solutions and suggest that 614 magma may have migrated to a shallower level during the Quaternary at the time of dike 615 emplacement. This lateral movement of the magma reservoirs, especially throughout the 616 lithosphere, is of great importance in understanding how magma moves in the brittle-upper crust 617 whilst being subjected to lithospheric deformations such as extrusion tectonics and block rotations.

\section{Acknowledgments}

619 This study was supported by funds of the Yüzüncü Yıl Üniversitesi (Project Nu. 2014-MIM620 B062). Özgür Karaoğlu is supported by The Scientific and Technological Research Council of 621 Turkey (TUBITAK) International Postdoctoral Research Fellowship Programme. We are grateful 622 to the Executive Editor Andrew Harris, Editor Valerio Acocella and the reviewers, Alessandro 623 Tibaldi, Nobuo Geshi and an anonymous reviewer, for comments which greatly improved this 624 work.

625

626

627

628 


\section{References}

632

633

634

635

636

637

638

639

640

Annen C, Pichavant M, Bachmann O, Burgisser A (2008) Conditions for the growth of a longlived shallow crustal magma chamber below Mount Pelee volcano (Martinique, Lesser Antilles Arc). J Geophys Res 113(B07209). doi:10.1029/2007JB005049.

Acocella V (2007) Understanding caldera structure and development: and overview of analogue models compared to natural calderas. Earth-Sci Rev 85:125-160.

Aldiss DT, Ghazali SA (1984) The regional geology and evolution of the Toba volcano-tectonic depression, Indonesia. J Geol Soc 141:487-500. doi:10.1144/gsjgs.141.3.0487.

Amedei B, Stefanson O (1997) Rock stress and its measurement. Chapman and Hall, London.

Bachmann O, Bergantz G (2008) The magma reservoirs that feed supereruptions. Elements 4(1):17-21.

Barka AA (1992) The North Anatolian Fault zone. Annales Tecton 6:164-195.

Barnett Z, Gudmundsson A (2014) Numerical modelling of dykes deflected into sills to form a magma chamber. J Volcanol Geotherm Res 281:1-11.

Becerril L, Galindo I, Gudmundsson A, Morales JM (2013) Depth of origin of magma in eruptions. Sci Rep 3:2762. doi:10.1038/srep02762.

Bistacchi A, Tibaldi A, Pasquarè FA, Rust D (2012) The association of cone-sheets and radial dykes: Data from the Isle of Skye (UK), numerical modelling, and implications for shallow magma chambers. Earth Planet Sc Lett 339-340:46-56.

Bonatti E, Harrison CGA (1988) Eruption styles of basalt in oceanic spreading ridges and seamounts: effect of magma temperature and viscosity. J Geophys Res 93:2967-2980.

Bower SM, Woods AW (1997) Control of magma volatile content and chamber depth on the mass erupted during explosive volcanic eruptions. J Geophys Res-Solid 102(B5):1027310290. doi:10.1029/96JB03176.

Bozkurt E (2001) Neotectonics of Turkey—a synthesis. Geodin Acta 14:3-30.

Browning J, Gudmundsson A (2015) Caldera faults capture and deflect inclined sheets: an alternative mechanism of ring dike formation. B Volcanol 77(1):4.

Browning J, Drymoni K, Gudmundsson A (2015) Forecasting magma-chamber rupture at Santorini Volcano, Greece. Sci Rep 5:15785. http://doi.org/10.1038/srep15785. 
672

673

674

675

676

677

678

679

680

681

682

683

684

685

686

687

688

689

690

691

692

693

694

695

696

697

698

699

700

701

702

703

704

705

706

707

708

709

710

711

712

713

714

715

716

717

Buket E, Temel A (1998) Major-element, trace element, and Sr-Nd isotopic geochemistry and genesis of Varto (Muş) volcanic rocks, eastern Turkey. J Volcanol Geotherm Res 85:405-422.

Burnett MS, Caress DW, Orcutt JA (1989) Tomographic image of the magma chamber at 12 50 'N on the East Pacific Rise. Nature 339:206-208. doi:10.1038/339206a0.

Caricchi L, Annen C, Blundy J, Simpson G, Pinel V (2014) Frequency and magnitude of volcanic eruptions controlled by magma injection and buoyancy. Nat Geosci 7(2):126.

Carracedo JC, Day S, Guillou H, Rodríguez Badiola E, Canas JA, Pérez Torrado FJ (1998) Hotspot volcanism close to a passive continental margin: the Canary Islands. Geol Mag 135:591604.

Cayol V, Dieterich JH, Okamura AT, Miklius A (2000) High magma storage rates before the 1983 eruption of Kilauea, Hawaii. Science 288(5475):2343-2346.

Chaussard E, Amelung F (2014) Regional controls on magma ascent and storage in volcanic arcs. Geochem Geophys Geosys 15:doi:10.1002/2013GC005216.

Chestler, SR, Grosfils EB (2013) Using numerical modeling to explore the origin of intrusion patterns on Fernandina volcano, Galapagos Islands, Ecuador. Geophys Res Lett 40(17):4565-4569.

Daniels KA, Bastow ID, Keir D, Sparks RSJ, Menand T (2014) Thermal models of dyke intrusion during development of continent-ocean transition. Earth Planet Sc Lett 385:145-153.

Delaney P, Pollard D (1981) Deformation of host rocks and flow of magma during growth of minette dikes and breccia-bearing intrusions near Ship Rock, New Mexico, U.S. Geol. Surv. Prof. Pap. 1202.

Dhont D, Chorowicz J (2006) Review of the neotectonics of the Eastern Turkish-Armenian Plateau by geomorphic analysis of digital elevation model imagery. International Journal of Earth Sciences 95(1):34-49.

Dvorak JJ, Dzurisin D (1997) Volcano geodesy: The search for magma reservoirs and the formation of eruptive vents. Rev Geophys 35(3):343-384. doi:10.1029/97RG00070.

Elshaafi A, Gudmundsson A (2017a) Distribution and size of lava shields on the Al Haruj al Aswad and the Al Haruj al Abyad Volcanic Systems, Central Libya. J Volcanol Geotherm Res 338:1-17.

Elshaafi A, Gudmundsson A (2017b) Mechanical interaction between volcanic systems in Libya. Tectonophysics. https://doi.org/10.1016/j.tecto.2017.11.031. 
Elshaafi A, Gudmundsson A (2016) Volcano-tectonics of the Al Haruj Volcanic Province, Central Libya. J Volcanol Geotherm Res 325:189-202.

Ernst RE, Grosfils EB, Mege D (2001) Giant dike swarms: Earth, venus, and mars. Annu Rev Earth Pl Sc 29(1):489-534.

Eychenne J, Houghton BF, Swanson DA. Carey RJ, Swavely L (2015). Dynamics of an open basaltic magma system: the 2008 activity of the Halema 'uma 'u Overlook vent, Kîlauea Caldera. Earth Planet Sc Lett 409:49-60.

Ferguson DJ., Gonnermann HM, Ruprecht P, Plank T, Hauri EH, Houghton BF, Swanson DA (2016). Magma decompression rates during explosive eruptions of Kĩlauea volcano, Hawaii, recorded by melt embayments. B Volcanol 78(10):71.

Galindo I, Gudmundsson A (2012) Basaltic feeder-dykes in rift zones: geometry, emplacement, and effusion rates. Nat Hazard Earth Sys 12:3683-3700.

Gerbault M (2012) Pressure conditions for shear and tensile failure around a cir-cular magma chamber, insight from elasto-plastic modelling. Geol Soc (Lond) Spec Publ 367 (1):111-130.

Geshi N, Kusumoto S, Gudmundsson A (2010) The geometric difference between non-feeder and feeder dikes. Geology 38:195-198.

Gök R, Mellors RJ, Sandvol E, Pasyanos M, Hauk T, Takedatsu R, Yetirmishli G, Teoman U, Türkelli N, Godoladze T, Javakishvirli Z (2011) Lithospheric velocity structure of the Anatolian Plateau-Caucasus-Caspian region. J Geophys Res 116:B05303.

Graeber F, Asch G (1999) Three-dimensional models of P wave velocity and P-to-S velocity ratio in the southern central Andes by simultaneous inversion of local earthquake data. J Geophys Res 104(B9):20237-20256. doi:10.1029/1999JB900037.

Gregg PM, De Silva SL, Grosfils EB (2013) Thermomechanics of shallow magma chamber pressurization: Implications for the assessment of ground deformation data at active volcanoes. Earth Planet Sc Lett 384:100-108.

Greenland LP, Rose WI, Stokes JB (1985) An estimate of gas emissions and magmatic gas content from Kilauea volcano. Geochim Cosmochim Ac 49:125-129.

Greenland LP, Okamura AT, Stokes JB (1988) Constraints on the mechanics of the eruption. In: Wolfe EW (Ed), The Puu Oo Eurption of Kilauea Volcano, Hawaii: episodes 1 through 20, January 3, 1983 Through June 8, 1984. US Geol Surv Prof Pap 1463:155-164.

Grosfils EB (2007) Magma reservoir failure on the terrestrial planets: assessing the importance of gravitational loading in simple elastic models. J Volcanol Geotherm Res 166(2):47-75. 
Grosfils EB, McGovern PJ, Gregg PM, Galgana GA, Hurwitz DM, Long SM, Chestler SR (2015). Elastic models of magma reservoir mechanics: a key tool for investigating planetary volcanism. Geol Soc (Lond) Spec Publ 401(1):239-267.

Gudmundsson A (1983) Form and dimensions of dykes in eastern Iceland. Tectonophysics 95(34):295-307.

Gudmundsson A (1987) Formation and mechanics of magma reservoirs in Iceland. Geophys J Int 91(1):27-41.

Gudmundsson A (1990) Emplacement of dikes, sills, and crustal magma chambers at divergent plate boundaries. Tectonophysics 176:257-275.

Gudmundsson A (1995) Infrastructure and mechanics of volcanic systems in Iceland. J Volcanol Geotherm Res 64(1):1-22.

Gudmundsson A (1999) Fluid overpressure and stress drop in fault zones. Geophys Res Lett 26: $115-118$.

Gudmundsson A (2000) Dynamic of volcanic systems in Iceland: Example of Tectonism and Volcanism at Juxtaposed Hot Spot and Mid-Ocean Ridge Systems. Annu Rev Earth Pl Sc 28:107-40.

Gudmundsson A (2006) How local stresses control magma-chamber ruptures, dyke injections, and eruptions in composite volcanoes. Earth-Sci Rev 79:1-31. doi:10.1016/j.earscirev 2006.06.006.

Gudmundsson A (2007) Conceptual and numerical models of ring-fault formation. J Volcanol Geotherm Res 164:142-160.

Gudmundsson A (2011) Rock Fractures in Geological Processes. Cambridge University Press, Cambridge.

Gudmundsson A (2012) Magma chambers: Formation, local stresses, excess pressures, and compartments. J Volcanol Geotherm Res 237:19-41.

Gudmundsson A (2015) Collapse-driven large eruptions. J Volcanol Geotherm Res 304:1-10.

Gudmundsson A (2016) The mechanics of large volcanic eruptions. Earth-Sci Rev 163:72-93.

Gudmundsson A (2018) Propagation paths of fluid-driven fractures. Geophys Res Abstr 20: EGU2018-15305.

Gudmundsson A, Andrew REB (2007) Mechanical interaction between active volcanoes in Iceland. Geophys Res Lett 34:L10310. 
Gurocak Z, Solanki P, Alemdag S, Zaman MM (2012) New considerations for empirical estimation of tensile strength of rocks. Eng Geol 145:1-8.

Italiano F, Sasmaz A, Yuce G, Okan OO (2013) Thermal fluids along the East Anatolian Fault Zone (EAFZ): Geochemical features and relationships with the tectonic setting. Chem Geol 339:103-114.

Jellinek AM, DePaolo DJ (2003) A model for the origin of large silicic magma chambers: precursors of caldera-forming eruptions. B Volcanol 65(5):363-381. doi: 10.1007/s00445-003-0277-y.

Haberland C, Rietbrock A (2001). Attenuation tomography in the western central Andes: A detailed insight into the structure of a magmatic arc. J Geophys Res 106(B6):1115111167. doi:10.1029/2000JB900472.

Hubert-Ferrari A, King G, Woerd J, Van der Villa I, Altunel E, Armijo R (2009) Long-term evolution of the North Anatolian Fault: new constraints from its eastern termination. Geol Soc (Lond) Spec Publ 311(1):133-154. doi: 10.1144/SP311.5.

Karaoğlu Ö, Özdemir Y, Tolluoğlu AÜ, Karabıyıkoğlu M, Köse O, Froger JL (2005) Stratigraphy of the volcanic products around Nemrut Caldera: implications for reconstruction of the Caldera Formation. Turk J Earth Sci 14:123-143.

Karaoğlu Ö, Browning J, Bazargan M, Gudmundsson A (2016) Numerical modelling of triplejunction tectonics at Karlova, Eastern Turkey, with implications for regional transport. Earth Planet Sc Lett 452:157-170. http://dx.doi.org/10.1016/j.epsl.2016.07.037.

Karaoğlu O, Elshaafi A, Salah M, Browning J, Gudmundsson A (2017a) Large-volume lava flows fed by a deep magmatic reservoir at Ağrı Dağı (Ararat) volcano, Eastern Turkey. Bull Volcanol 79:15. http://dx.doi.org/10.1007/s00445-016-1098-0.

Karaoğlu Ö, Sağlam-Selçuk A, Gudmundsson A (2017b) Tectonic controls on the Karlıva triple junction (Turkey): implications for tectonic inversion and the initiation of volcanism. Tectonophysics 694:368-384.

Kavanagh JL, Boutelier D, Cruden AR (2015) The mechanics of sill inception, propagation and growth: experimental evidence for rapid reduction in magmatic overpressure. Earth Planet Sci Lett 421:117-128.

Konstantinou KI, Lin CH, Liang WT (2007) Seismicity characteristics of a potentially active Quaternary volcano: the Tatun Volcano Group, northern Taiwan. J Volcanol Geotherm Res 160:300-318.

Kushiro I (1980) Viscosity, density, and structure of silicate melts at high pressures, and their petrological applications. In: R.B. Hargraves (Editor), Physics of Magmatic Processes. Princeton University Press, Princeton, NJ pp. 93-120. 
852

853

854

855

856

857

858

859

860

861

862

863

864

865

866

867

868

869

870

871

872

873

874

875

876

877

878

879

880

881

882

883

884

885

886

887

888

889

890

891

892

893

894

Kusumoto S, Geshi N, Gudmundsson A (2013) Inverse modeling for estimating fluid-overpressure distributions and stress intensity factors from arbitrary open-fracture geometry. J Struct Geol 46:92-98.

Kusumoto S, Gudmundsson A (2014) Displacement and stress fields around rock fractures opened by irregular overpressure variations. Frontiers Earth Sci 2: doi: 10.3389/feart.2014.00007.

Le Corvec N, Spörli KB, Rowland J, Lindsay J (2013) Spatial distribution and alignments of volcanic centers: clues to the formation of monogenetic volcanic fields. Earth-Science Reviews 124:96-114.

Lees J (2007) Seismic tomography of magmatic systems. J Volcanol Geotherm Res 167(1-4):3756. doi:10.1016/j.jvolgeores.2007.06. 008.

Lemnifi A, Elshaafi A, Karaoğlu Ö, Salah M, Aouad N, Reed C, Yu Y (2017a) Complex seismic anisotropy and mantle dynamics beneath Turkey. J Geodyn 112:31-45.

Lemnifi A, Elshaafi A, Browning J, El Ebadi S, Gudmundsson A (2017b) Crustal thickness beneath Libya and the origin of partial melt beneath AS Sawda Volcanic Province from receiver-function constraints. J Geophys Res 122. doi:10.1002/2017JB014291.

Lipman PW (1997) Subsidence of ash-flow calderas: relation to caldera size and magma chamber geometry. B Volcanol 59:198-218. doi:10.1007/s004450050186.

Longpré MA, Troll VR, Hansteen TH (2008) Upper mantle magma storage and transport under a Canarian shield-volcano, Teno, Tenerife (Spain). J Geophys Res-Solid 113(B8).

Macdonald K (1986) The crest of the Mid-Atlantic Ridge: Models for crustal generation processes and tectonics. In: P.R. Vogt and B.E. Tucholke (Editors), The Geology of North America, Vol. M. The Western North Atlantic Region. Geol Soc Am, New York, NY pp. 51-68.

MacLeod CJ, Yaouancq G (2000) A fossil melt lens in the Oman ophiolite: implications for magma chamber processes at fast spreading ridges. Earth Planet Sc Lett 176:357-373.

Martel C, Pichavant M, Bourdier JL, Traineau H, Holtz F, Scaillet B (1998) Magma storage conditions and control of eruption regime in silicic volcanoes: experimental evidence from Mt. Pelée. Earth Planet Sc Lett 156:89-99. doi:10.1016/S0012821X(98)00003-X.

Marti J Gudmundsson A (2000) The Las Cañadas caldera (Tenerife, Canary Islands): an overlapping collapse caldera generated by magma-chamber migration. J Volcanol Geotherm Res 103:161-173.

Middlemost EA (1997) Magmas, Rocks and Planetary Development: A Survey of Magma/Igneous Rock Systems. Routledge, Oxford. 
Mogi K (1958) Relations between eruptions of various volcanoes and the deformations of the ground surfaces around them. B Earthq Res Inst 36:99-134.

Moussallam Y, Edmonds M, Scaillet B, Peters N, Gennaro E, Sides I, Oppenheimer C (2016). The impact of degassing on the oxidation state of basaltic magmas: a case study of Kîlauea volcano. Earth Planet Sc Lett 450:317-325.

Murase T, McBirney AR (1973) Properties of some common igneous rocks and their melts at high temperatures. Geol Soc Am Bull 84:3563-3592.

Ofeigsson BG, Hooper A, Sigmundsson F, Sturkell E, Grapenthin R (2011) Deep magma storage at Hekla volcano, Iceland, revealed by InSAR time series analysis. J Geophys Res-Solid 116(B5).

Okay AI, Tüysüz O (1999) Tethyan sutures of northern Turkey. Geol Soc (Lond) Spec Publ 156(1):475-515.

Orcutt J, McClain J, Burnett M (1984) Evolution of the ocean crust: results from recent seismic experiments. In: LG. Gass, S.J. Lippard and A.W. Shelton (Editors), Ophiolites and Oceanic Lithosphere. Blackwell, Oxford, pp.7-16.

Parsons T, Thompson GA (1991) The Role of Magma Overpressure in Suppressing Earthquakes and Tomography: Worldwide Examples. Science 253(5026):1399-1402.

Pearce JA et al. (1990) Genesis of collision volcanism in eastern Anatolia, Turkey. J Volcanol Geotherm Res 44:189-229.

Philipp SL (2012) Fluid overpressure estimates from the aspect ratios of mineral veins. Tectonophysics 581:35-47.

Peltier A, Famin V, Bachèlery P, Cayol V, Fukushima Y, Staudacher T (2008) Cyclic magma storages and transfers at Piton de La Fournaise volcano (La Réunion hotspot) inferred from deformation and geochemical data. Earth Planet Sc Lett 270(3):80-188. doi:10.1016/j.epsl.2008.02.042.

Pinel V, Jaupart C (2004) Magma storage and horizontal dyke injection beneath a volcanic edifice. Earth Planet Sc Lett 221(1):245-262. doi:10.1016/S0012-821X(04)00076-7.

Pistone M, Whittington AG, Andrews BJ, Cottrell E (2017). Crystal-rich lava dome extrusion during vesiculation: An experimental study. J Volcanol Geotherm Res 347:1-14.

Poidevin JL (1998) Provenance studies of obsidian artefacts in Anatolia using the fission track dating method, an overview. In: Gourgaud A, Gratuze B, Poupeau G, Poidevin JL, Cauvin, MC (Eds.), L'Obsidienne au Proche et Moyen Orient, du Volcan a` l'Outil. BAR International Series Hadrian Books, 738 pp. 105-156. 
Pollard D, Segall P (1987) Theoretical displacement and stresses near fractures in rocks: With application to faults, points, veins, dykes, and solution surfaces, in Fracture Mechanics of Rock, edited by BK., Atkinson, Academic Press, London, 277-349.

Reed C, Almadani S, Gao S, Elsheikh A, Cherie S, Abdelsalam M, Liu K (2014) Receiver function constraints on crustal seismic velocities and partial melting beneath the Red Sea rift and adjacent regions, Afar Depression. J Geophys Res-Solid 119:2138-2152. https://doi.org/10.1002/2013JB010719.

Reilinger R et al. (2006) GPS constraints on continental deformation in the Africa-ArabiaEurasia continental collision zone and implications for the dynamics of plate interactions. J Geophys Res 111:B05411.

Salah MK, Şahin Ş, Aydin U (2011) Seismic velocity and Poisson's ratio tomography of the crust beneath east Anatolia. J Asian Earth Sci 40:746-761. doi:10.1016/j.jseaes.2010.10.021.

Sançar C, Zabcı C, Akyüz HS, Sunal G, Villa IM (2015) Distributed transpressive continental deformation: The Varto Fault Zone, eastern Turkey. Tectonophysics 661:99-111.

Sanford A, Einarsson P (1982). Magma chambers in rifts. In: G. Palmason (Editor), Continental and Oceanic Rifts. Am Geophys Union Geodyn Ser 8:147-168.

Scandone R, Cashman KV, Malone SD (2007) Magma supply, magma ascent and style of volcanic eruptions. Earth Planet Sci Lett 253:513-529.

Singh SC, Crawford WC, Carton H, Seher T, Combier V, Cannat M, Canales JP, Dusunur D, Escartin J, Miranda M (2006) Discovery of a magma chamber and faults beneath a midatlantic ridge hydrothermal field. Nature 442:1029-1032.

Sneddon, I.N, Lowengrub, M. (1969) Crack Problems in the Classical Theory of Elasticity. New York: Wiley

Stachnik JC, Dueker K, Schutt DL, Yuan H (2008) Imaging Yellowstone plume-lithosphere interactions from inversion of ballistic and diffusive Rayleigh wave dispersion and crustal thickness data. Geochem Geophy Geos 9:Q06004. doi:10.1029/2008GC001992.

Stankiewicz J, Ryberg T, Haberland C, Natawidjaja D (2010) Lake Toba volcano magma chamber imaged by ambient seismic noise tomography. Geophys Res Lett 37(17).

Şengör AMC (2014) Triple junction. Encyclopedia of Marine Geosciences: pp. 1-13. http://dx.doi.org/10.1007/978-94-007-6644-0_122-1.

Şengör AMC, Yılmaz Y (1981) Tethyan evolution of Turkey: a plate tectonic approach. Tectonophysics 75:181193203-190199241. 
Şengör AMC, Görür N, Şaroğlu F (1985) Strike-slip faulting and related basin formation in zones of tectonic escape: Turkey as a case study. In: Biddle, KT, Christie-Blick N (Eds.), Strike Slip Faulting and Basin Formation. Soc Econ Pa 37:227-267.

Şengör AMC, Tüysüz O, Imren C, Sakınç M, Eyidogan H, Görür N, Le Pichon X, Rangin C (2004) The north Anatolian fault: a new look. Annu Rev Earth Planet Sci 33:37-112.

Tibaldi A Pasquarè FA (2008) A new mode of inner volcano growth: The flower intrusive structure. Earth Planet Sci Lett 271(1-4):202-208.

Türkünal S (1980) Doğu ve Güneydoğu Anadolu'nun jeolojisi. TMMOB Jeoloji Mühendisleri Odas1.

Troll V, Walter TR, Schmincke HU (2002) Cyclic caldera collapse: piston or piecemeal subsidence? Field and experimental evidence. Geology 30:135-138. doi:10.1130/0091-7613(2002)030<0135.

Valko P, Economides MJ (1995) Hydraulic Fracture Mechanics. New York: Wiley.

Walker GP (1986) Koolau Dike Complex, Oahu: Intensity and origin of a sheeted-dike complex high in a Hawaiian volcanic edifice. Geology 14(4):310-313.

West M, Menke W, Tolstoy M, Webb S, Sohn R (2001) Magma storage beneath axial volcano on the Juan de Fuca mid-ocean ridge. Nature 413:833-836.

Yew CH (1997) Hydraulic Fracture Mechancis. Houston. Gulf Professional Publishing.

Zhao D, Hasegawa A, Horiuchi S (1992) Tomographic imaging of P- and S-wave velocity structure beneath northeastern Japan. J Geophys Res 97:19909-19928.

Zhao D, Hasegawa A, Kanamori H (1994) Deep structure of Japan subduction zone as derived from local, regional and teleseismic events. J Geophys Res 99:22313-22329.

Zhao D, Wang K, Rogers G, Peacock S (2001) Tomographic image of low P velocity anomalies above slab in northern Cascadia subduction zone. Earth Planets Space 53:285-293.

Zhao D, Yanada T, Hasegawa A, Umino N, Wei W (2012) Imaging the subducting slabs and mantle upwelling under the Japan Islands. Geophys J Int 190:816-828. 
1021 Zor E, Sandvol E, Gürbüz C, Türkelli N, Seber D, Barazangi M (2003) The crustal 1022 structure of the East Anatolian plateau (Turkey) from receiver functions. Geophys Res 1023 Lett 30(24).

1024

1025

1026

1027

1028

1029

1030

1031

1032

1033

1034

1035

1036

1037

1038

1039 
1041 Fig. 1. a) Tectonic map of Turkey; b) rose diagram showing the distribution and abundance of dikes in the research area; c) DEM (compiled from the Shuttle Radar Topography Mission)derived map showing the locations of the measured dikes (black lines). NAF: North Anatolian Fault, EAF: Eastern Anatolian Fault, KTJ: Karliova Triple Junction, VFZ: Varto Fault Zone, CF: 1045 Çaldıran Fault.

1046 Fig. 2. a) Location of dikes at the three volcanoes (Vc: Varto caldera; Tv: Turnadağ volcano; Öv: Özenç volcano); b) a dike at Turnadağ volcano with the dike dimensions annotated (length = strike dimension; depth = dip dimension; thickness = opening); c) examples of fingers from dikes/dikelets between the Karlıva and Turnadağ volcanoes; d) Satellite imagery (adapted from Map Data: DigitalGlobe) showing the Varto caldera, $8 \mathrm{~km}$ in diameter, and the location of Figure 2e which is marked by a yellow box; e) a dike in the Varto caldera, indicated by a red dashed curve.

1054 1055

1056

Fig. 3. a-b) Dikes as seen in the western caldera wall of the Varto volcano.

Fig. 4. The main structures of Varto caldera projected on a Map Data: DigitalGlobe image. The structures include the main ring fault (caldera rim) as well as two smaller but concentric ring faults, making the caldera nested.

Fig. 5. a) Map Data: DigitalGlobe of dikes at Özenç volcanic area; b, c, and d) are images of dikes and volcanic fissures at the Özenç volcanic area.

Fig. 6. Two E-W (a;b) and one N-S (c), vertical cross sections of P-wave (Vp), S-wave (Vs), and Poisson's ratio $(v)$ structures beneath the Varto caldera, Turnadağ volcano and Özenç volcano areas at Karliova, Eastern Turkey. High Vp and Vs values and low $v$ values are shown in blue; whereas $\mathrm{Vp}$ and $\mathrm{Vs}$ values and high $v$ values are shown in red. The color scale of velocities ranges from -3 to $5 \%$ (in part a); from -4 to $4 \%$ (in part b), and from -3 to $4 \%$ (in part c). The small circles and large stars denote background and moderate/large seismic events, respectively, in a 30-kmwide zone around each profile.

Fig. 7. Schematic cartoon indicating a possible configuration of magma chambers, reservoirs, and dikes in relation to faults in the volcanic province of the Karlova region, Eastern Turkey. VFZ: Varto Fault Zone; NAFZ: North Anatolian Fault Zone, EAFZ: Eastern Anatolian Fault Zone.

Fig. 8. Aspect ratio of thickness $(\Delta \mathrm{u} 1)$ to length $(\mathrm{L})$ of the measured dikes against the calculated magma overpressures, measured at El Hierro, Canaria Islands (2*: Becerril et al. 2013), VartoKarlıova, Turkey and Al Haruj, Libya (3**: Elshaafi and Gudmundsson 2017b)

Table 1: Dike parameter values for Varto caldera, Turnadağ volcano and Özenç volcanic areas. The columns are as follows: thickness of the dike $\left(\Delta u_{I}\right)$, calculated magma overpressure in the dike $\left(p_{o}\right)$, along strike length of the dike $(L)$, the average density of the magma in the dike $\left(\rho_{m}\right)$, calculated depth of origin of the dike $(h)$, and strike of the dike. Some constant values are used as 
1077 follows: Poisson'ratio $(v)$ is 0.25 , Young's modulus of the host rock $(E)$ is $5 \mathrm{GPa}$, the average 1078 density of the host rock $\left(\rho_{r}\right)$ is $2800 \mathrm{~kg} \mathrm{~m}^{-3}$, internal excess magmatic pressure in the chamber ( $\left.1079 p_{e}\right)$ is $3.5 \mathrm{MPa}$, acceleration due to gravity $(g)$ is 9.81 , and the differential stress $\left(\sigma_{d}\right)$ is $1 \mathrm{MPa}$. 